\title{
Climatic and environmental factors influencing occurrence and distribution of macroalgae - a fjord gradient revisited
}

\author{
Kjersti Sjøtun ${ }^{1, *}$, Vivian Husa $^{1,2}$, Lars Asplin ${ }^{2}$, Anne Dagrun Sandvik ${ }^{2}$ \\ ${ }^{1}$ Department of Biology, University of Bergen, PO Box 7803,5020 Bergen, Norway \\ ${ }^{2}$ Institute of Marine Research, PO Box 1870 Nordnes, 5817 Bergen, Norway
}

\begin{abstract}
During the last decades, trends of increasing sea water temperatures and precipitation have been observed in the North Atlantic. Increasing sea water temperatures are expected to have strong effects on coastal benthic species. Here, the distributions of macroalgae were correlated to hydrographical indexes determined from measurements at sampling and hydrographical stations along the fjord during 2 investigation periods: 1955-1956 and 2008-2009. The following indexes were used: annual maximum sea temperature, minimum salinity, and salinity stress (calculated as the difference between maximum and minimum salinity). In addition, changes in macroalgal species abundance and distribution range in the fjord were calculated. The hydrographical measurements showed higher summer temperatures and reduced salinity stress due to lower winter salinity during 2008-2009. Results from constrained ordination analyses showed that the highest variation of the macroalgal distributions along the fjord was explained by hydrographical indexes from $5 \mathrm{~m}$ depth, and that there were strong response differences between the algal groups. The red algae were most strongly and positively correlated with the maximum temperature gradient, and also negatively correlated with increasing salinity stress. Many red algae species also increased in abundance and their distribution ranges shifted further into the fjord in 2008-2009. The brown algae showed the highest negative correlation with increasing salinity stress, and less change in abundance or range shifts along the fjord. Some brown algae species showed a strong correlation with temperature (positive or negative). These results demonstrate that both temperature and salinity changes will impact cold temperate macroalgal communities.
\end{abstract}

KEY WORDS: Macroalgal community - Hydrography - Climate change - Fjord gradient · Species composition

\section{INTRODUCTION}

The coast is extensively used and densely inhabited in many regions, and under great pressure worldwide. Macroalgae dominate the vegetation in the intertidal and the euphotic zone, and consequently, their occurrence and abundance may be strongly affected by anthropogenic activity (Walker \& Kendrick 1998). Reports of conspicuous changes in macroalgal composition and abundances are due

*Corresponding author: kjersti.sjotun@uib.no to anthropogenic impacts such as nutrient enrichment (e.g. Valiela et al. 1997, Middelboe \& SandJensen 2000, Worm \& Lotze 2006, Liu et al. 2013), interactions between nutrient enrichment and grazers (Lotze \& Worm 2000), and increased sedimentation (Eriksson et al. 2002, Eriksson \& Johansson 2005). More recently there has been a strong focus on effects of increasing sea temperatures in coastal areas, and a number of cases with concurrent changes in macroalgae range shifts (e.g. Lima et al.

() The authors 2015. Open Access under Creative Commons by Attribution Licence. Use, distribution and reproduction are unrestricted. Authors and original publication must be credited. 
2007, Dìez et al. 2012, Tanaka et al. 2012, Duarte et al. 2013) or community compositions (e.g. Husa et al. 2008, Dìez et al. 2012, Sangil et al. 2012) have been reported.

Sea temperature and salinity are usually the main physical factors which determine regional and local distributions of macroalgae in euphotic coastal waters. For most macroalgal species the seasonal temperature extremes, sometimes in combination with day lengths, set biogeographical boundaries for survival, growth or reproduction (van den Hoek 1982a,b, Breeman 1988, Lüning 1990). In addition to temperature tolerance limits, most macroalgae also have optimum temperature ranges for photosynthesis and growth. For European cold-temperate algae the optimum temperature for growth is often around $15^{\circ} \mathrm{C}$, or in the range between 10 and $15^{\circ} \mathrm{C}$ (Fortes \& Lüning 1980). In addition to affecting survival and growth rate, temperature may also influence the functionality of macroalgae in other ways such as influencing fecundity and thereby local abundance. For example, Krueger-Hadfield et al. (2013) observed that reproductive effort in the red alga Mastocarpus papillatus was positively correlated with temperature. Local variation in salinity will also set physiological tolerance limits for marine macroalgae, or affect growth and functionality in several ways (Kirst 1990). In estuaries, where salinity of the surface waters varies with precipitation and freshwater run-off from land, macroalgal communities are likely to be dominated by euryhaline species with wide tolerance limits.

Variation in sea temperature and other marine physical factors is due to both natural variability and to anthropogenic activity. Inter-annual variability is typically the result of large scale weather patterns as, for example, described by the North Atlantic Oscillation index (NAO) (Lifland 2003). Anthropogenically induced variability of physical factors is to a large extent due to greenhouse gas induced climatic changes resulting in increased temperatures and precipitation (Scavia et al. 2002). During the last decades increased sea temperatures and precipitation have been observed in the North Atlantic (Benestad \& Melsom 2002, Lenderink et al. 2009). Elevated temperatures and increased freshwater run-off to the sea, causing lower salinity, may be especially pronounced in estuaries. While increased precipitation may have resulted in an overall increase in freshwater run-off to estuaries, the establishment of hydroelectric power plants has caused a strong intraannual change in freshwater run-off to many fjords in Norway. Snow melting during spring and early summer results in high freshwater run-off to the sea and causes the formation of a pronounced brackish layer in the fjords during this period. Approximately $70 \%$ of the large river systems in Norway have now been regulated for hydroelectric power plant production (Myksvoll et al. 2014), with the main part being regulated after 1960 (Kaartvedt 1984). The regulation includes making basins for retaining water, and as a result of this, the seasonal pattern with a pronounced peak in freshwater discharge during spring and early summer has changed in many of the fjords (Kaartvedt 1984).

Large scale and mainly climate-driven changes have recently been observed in coastal ecosystems (Harley et al. 2006, Parmesan 2006, Aksnes et al. 2009, Iles et al. 2012, Hernández-Fariñas et al. 2014). The more long-lasting the fluctuations in the physical environment, the greater the ecosystem impacts (Sundby \& Nakken 2008). The most marked ecological effects of such changes include altered composition of trophic groups and foodwebs. Thus, analyzing climate-driven changes in the composition of different trophic levels is imperative in understanding ecosystem effects, and this can only be done by utilizing historical data. Here, changes in macroalgal distributions between 2 investigation periods: 1955-1956 and 2008-2009, at a total of 20 stations in Hardangerfjord have been analyzed in relation to hydrographical data corresponding to those time periods. The data of the macroalgal distribution in 1955-1956 have previously been published in Jorde \& Klavestad (1963) and the stations were reinvestigated by Husa et al. (2014), who observed an increase in number of species per station and a higher occurrence of species with a more southern distribution in 2008-2009 compared to the data from 1955-1956. Husa et al. (2014) suggested that the changes were caused by hydrographical changes, but did not provide any analyses of the macroalgal data in relation to hydrographical data. Here, we have compiled data on temperature and salinity along Hardangerfjord from 1955-1956 and 2008-2009. The temperature and salinity profiles were different between the 2 periods, which enabled us to demonstrate significant correlations between algal distributions and environmental gradients derived from the hydrographical datasets. Furthermore, we related these correlation patterns to changes in macroalgal species abundances and distribution shifts along the fjord. Subsequently, we were able to show differences between algal groups with regard to environmental responses, and to examine in detail response differences between species. 


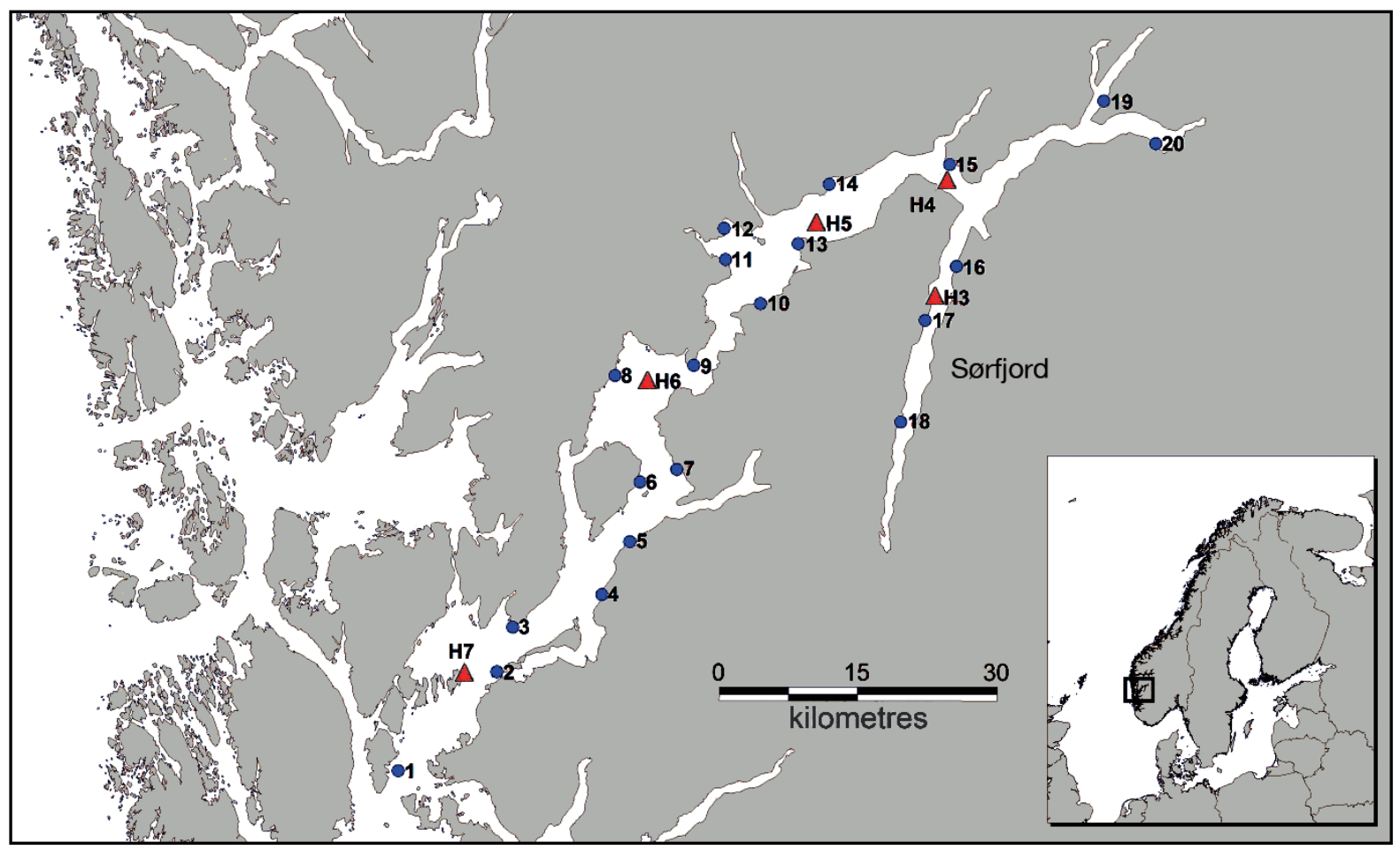

Fig. 1. Map of Hardangerfjord study area with macroalgal sampling (1-20) and hydrographical stations (H3-H7)

\section{MATERIALS AND METHODS}

\section{Hydrography}

Data describing the variability in the Hardangerfjord region sea temperature over the last 60 yr were obtained from the Utsira coastal monitoring station, operated by the Institute of Marine Research, Norway. The Utsira station $\left(59^{\circ} 18^{\prime} \mathrm{N}, 04^{\circ} 52^{\prime} \mathrm{E}\right)$ is situated approximately $25 \mathrm{~km}$ southwest of the outside mouth of Hardangerfjord, and the monthly mean temperature values at $10 \mathrm{~m}$ depth are within the same ranges as high frequency observations from inside Hardangerfjord (Asplin et al. 2014). At Utsira station, bi-weekly salinity and temperature profiles date back to 1942 (Sætre et al. 2003).

Salinity and temperature were measured in Hardangerfjord monthly at 0, 5 and $10 \mathrm{~m}$ depths at 5 stations (H3-H7) distributed along the fjord gradient (Fig. 1) during 1955-1956 (Sælen 1962). These data were compared to recent data collected at irregular intervals (from every month to every 4 months) during 2008 and 2009, and supplemented with additional measurements from 1992 and 1993 from locations close to Stn H3 and H4 (data from 5 and $10 \mathrm{~m}$ during the months November 1992 and June, August and September 1993). The hydrographical record- ings from 2008-2009 do not include measurements from Stn H6. Data from H6 were substituted by the averages of measurements collected at 2 new hydrographical stations placed around $8 \mathrm{~km}$ further inside the fjord from Stn H6 and $10 \mathrm{~km}$ seaward of Stn H6.

The long-term trend in precipitation was derived from monthly recordings from a weather station situated close to Stn 20 (Fig. 1), in the inner part of the Hardangerfjord area (data available from the Norwegian Meteorological Institute: http://eklima.met.no).

In order to evaluate the effect of hydroelectric power plant constructions in Hardangerfjord, the freshwater run-off data from an unregulated river and from a nearby hydroelectric power plant at the head of Hardangerfjord in the largest fjord branch Sørfjord (Fig. 1) were compared (data available from the Norwegian Water Resources and Energy Directorate: www.nve.no/vann-og-vassdrag/Datadatabaser) (Petterson 2008).

\section{Macroalgae communities}

The macroalgal dataset used in the present study consists of presence-absence recordings of species from 20 shore stations situated from the outer part of Hardangerfjord to the innermost fjord branches. Sta- 
tions 1-15 are placed in the Hardangerfjord proper, and Stns 16-20 in fjord branches (Fig. 1). Stations were first investigated during the summers of 1955 and 1956 (Jorde \& Klavestad 1963), and recently during June-July in 2008 and 2009 (Husa et al. 2014). Sampling during 2008-2009 was carried out using the methods and dredging depths as described in Jorde \& Klavestad (1963). The majority (19 of 20) of stations sampled during 1955-1956 were sampled in 1955, and in 2008-2009, 7 stations were sampled in 2008 and 13 in 2009. Macroalgae were collected from intertidal (at low tide by hand) and subtidal (dredging from a boat at 5-21 m depths) areas at each station. Taxa were sampled and identified to species level when possible, according to Husa et al. (2014); very small species $(<1 \mathrm{~cm})$, crustose species and species with uncertain taxonomic status were not included. Species recently introduced to Norway (since 1956) were also not included in the analyses.

A pronounced gradient in macroalgal species richness was found along the fjord during both the early (1955-1956) and recent (2008-2009) investigations, with a decrease in number of species with increasing distance to the mouth of the fjord (Jorde \& Klavestad 1963, Husa et al. 2014). In order to examine whether species exhibited changes in range distribution along the fjord, data from the 2 investigations were utilized for calculating range shifts between the 2 studies. The distance along the fjord from the outermost to the innermost station in the longest fjord branch was $126 \mathrm{~km}$. The distance was divided by number of stations $(\mathrm{n}=18)$ along the fjord length resulting in 18 sectors, each $7 \mathrm{~km}$ long, and when adding the sectors in the other fjord branches this gave an average distribution of 1.1 stations per sector. The sectors were numbered, and the difference in number of sectors between the innermost sectors in which each of the species was recorded during the 2 investigations was noted. In order to reduce the effect of randomly occurring rare species, only species recorded at more than 2 stations during one or both of the investigations were included.

In order to calculate concurrent changes in each species' local abundance in the fjord between the 2 studies, the frequencies of each species within their distribution ranges were calculated. The abundance of each species was calculated as the frequency of occurrence between the innermost station where a species was present and the outermost station (Stn 1). Only species recorded at more than 2 stations during one or both of the investigations were included. The relative change in abundance for each species was calculated as difference in frequency from 19551956 to 2008-2009.
In order to test whether changes in macroalgal distributions between 1955-1956 and 2008-2009 could be related to hydrographical factors, the distributions during the 2 periods were correlated to hydrographical indexes constructed from measurements at the hydrographical Stns H3-H7 during the 2 investigation periods. The 2 successive years of both periods did not differ much in their extreme values of temperature and salinity, and the measurements during each period were compiled in order to make the indexes. Macroalgae have been shown to respond quickly to environmental changes (Pedersen et al. 2008). Since extreme values for hydrographical variables over the year are most likely to have an influence on survival or growth of macroalgae, seasonal maximum and minimum values of temperature and salinity were used in the analyses. Temperature and salinity of the surface water may be prone to large short-term variations due to day-to-day variations in rainfall, air temperature or the horizontal advection of water masses, therefore, the recordings from 5 and $10 \mathrm{~m}$ depth were used to construct salinity and temperature indexes. The following environmental indexes were constructed: annual maximum temperature $\left(\mathrm{T}_{\max }\right)$, annual minimum salinity $\left(\mathrm{S}_{\mathrm{min}}\right)$, and salinity stress $\left(\mathrm{S}_{\text {str }}\right)$. Salinity stress was calculated as the maximum annual difference of the salinity measurements at each hydrographical station. Annual minimum temperature was not included since it did not differ much between the 2 investigation periods or between the hydrographical stations. The calculated index values for each hydrographical station were then assigned to the closest macroalgae stations. Index values were interpolated for areas between Stns H7 and H6, and Stns H6 and H5, and the resulting values were assigned to the macroalgae stations between each hydrographical station.

Correlations between species distributions and the temperature and salinity indexes during the early (1955-1956) and recent (2008-2009) investigation periods were performed using a direct gradient analysis with constrained ordination (linear Constrained Redundancy Analysis [RDA]) (Lepš \& Šmilauer 2003) and Monte Carlo permutation tests with unrestricted permutations for significance; all analyses were performed in CANOCO Ver. 4.5. Results from Stns 19 and 20 were not included in the ordination analyses, since these were placed in separate fjord branches with no recent hydrographical measurements nearby. Likewise, species recorded only once during one or both investigations, and species with the same distribution during both studies or 
with only $\sim 1$ recording during one of the investigations, were omitted. A total of 78 macroalgae species were included in the ordination analyses: 5 Chlorophyta (green algae), 36 Phaeophyceae (brown algae) and 37 Rhodophyta (red algae) (Appendix 1). Analyses were carried out separately for the distributions of green, brown and red algae.

\section{RESULTS}

\section{Hydrography}

Temperature plots from the hydrographical stations in Hardangerfjord (H3-H7) during 1955-1956 and 2008-2009 are shown in Fig. 2. Whilst the mini-
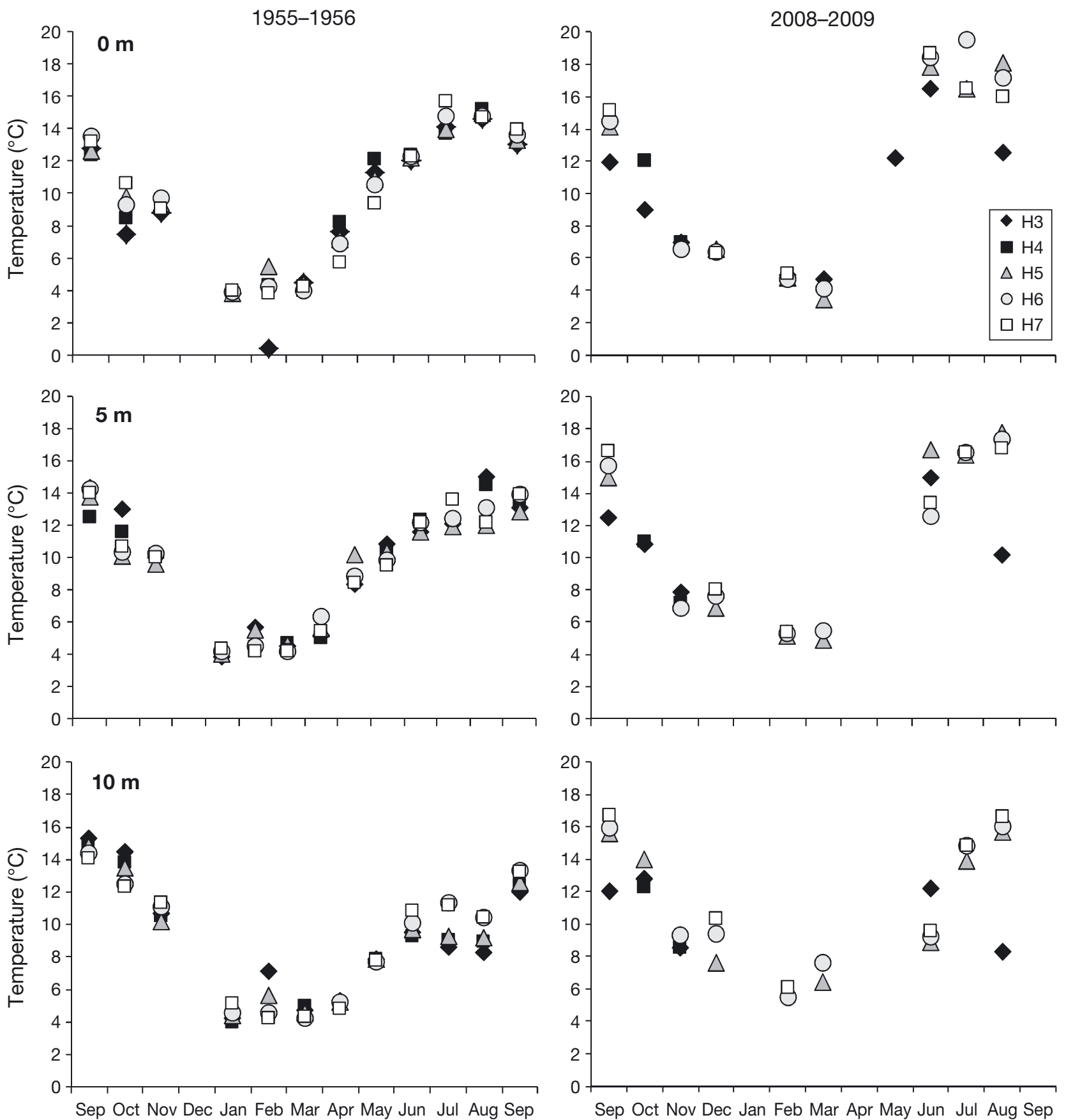

Fig. 2. Temperature recordings at 0, 5 and $10 \mathrm{~m}$ depths at Stns H3-H7 during earlier (1955-1956) and recent (2008-2009) investigation periods. The data plots for H6 in 2008-2009 consist of measurement averages from 2 new hydrographical stations, placed $8 \mathrm{~km}$ further inside the fjord from Stn H6 and $10 \mathrm{~km}$ seaward of H6 
Table 1. Overview of environmental indexes based on measurements from $5 \mathrm{~m}$ depth at hydrographical Stns H3-H7, used in ordination and RDA analyses of macroalgal species distributions at shore Stns 1-18. Index values for the 2 periods are indicated by suffixes 1955-1956 and 2008-2009. $\mathrm{T}_{\max }=$ maximum temperature, $\mathrm{S}_{\mathrm{str}}=$ salinity stress, and $\mathrm{S}_{\min }=$ salinity minimum; changes in environmental indexes between the 2008-2009 and 1955-1956 investigation periods are displayed in italics. Locations of the hydrographical Stns H3-H7 are shown in relation to shore stations (numbered). Indexes are interpolated between Stns $\mathrm{H} 7$ to H6, and H6 to H5

\begin{tabular}{|c|c|c|c|c|c|c|c|c|c|c|c|c|c|c|c|c|c|c|}
\hline $\begin{array}{l}\text { Hydrographical stn: } \\
\text { Station: }\end{array}$ & $\begin{array}{c}\mathrm{H} 7 \\
1\end{array}$ & $\begin{array}{c}\mathrm{H} 7 \\
2\end{array}$ & 3 & 4 & 5 & 6 & 7 & $\begin{array}{c}\mathrm{H} 6 \\
8\end{array}$ & $\begin{array}{l}\mathrm{H} 6 \\
9\end{array}$ & 10 & 11 & 12 & $\begin{array}{l}\mathrm{H} 5 \\
13\end{array}$ & $\begin{array}{l}\mathrm{H} 5 \\
14\end{array}$ & $\begin{array}{l}\mathrm{H} 4 \\
15\end{array}$ & $\begin{array}{l}\mathrm{H} 3 \\
16\end{array}$ & $\begin{array}{l}\mathrm{H} 3 \\
17\end{array}$ & $\begin{array}{c}\mathrm{H} 3 \\
18\end{array}$ \\
\hline $\mathrm{T}_{\max } 1955-1956$ & 14 & 14 & 14 & 14 & 14.1 & 14.1 & 14.1 & 14.1 & 14.1 & 13.7 & 13.7 & 13.7 & 13.3 & 13.3 & 14.1 & 14.7 & 14.7 & 14.7 \\
\hline $\mathrm{T}_{\max } 2008-2009$ & 16.8 & 16.8 & 16.9 & 17 & 17.1 & 17.2 & 17.3 & 17.4 & 17.4 & 17.6 & 17.6 & 17.6 & 17.8 & 17.8 & 16.4 & 15 & 15 & 15 \\
\hline$\Delta \mathrm{T}_{\max }$ & 2.8 & 2.8 & 2.9 & 3 & 3 & 3.1 & 3.2 & 3.3 & 3.3 & 3.9 & 3.9 & 3.9 & 4.5 & 4.5 & 2.3 & 0.3 & 0.3 & 0.3 \\
\hline $\mathrm{S}_{\text {str }} 1955-1956$ & 3.6 & 3.6 & 5.1 & 6.6 & 8.1 & 9.6 & 11.1 & 12.6 & 12.6 & 13.3 & 13.3 & 13.3 & 14 & 14 & 17.9 & 17.1 & 17.1 & 17.1 \\
\hline $\mathrm{S}_{\mathrm{str}} 2008-2009$ & 5.9 & 5.9 & 6.4 & 6.9 & 7.4 & 7.9 & 8.4 & 9 & 9 & 10.3 & 10.3 & 10.3 & 11.6 & 11.6 & 10.3 & 7.3 & 7.3 & 7.3 \\
\hline$\Delta S(s t r)$ & 2.3 & 2.3 & 1.3 & 0.3 & -0.7 & -1.7 & -2.7 & -3.6 & -3.6 & -3 & -3 & -3 & -2.4 & -2.4 & -7.6 & -9.8 & -9.8 & -9.8 \\
\hline$S_{\min } 1955-1956$ & 24.2 & 24.2 & 23.6 & 23 & 22.4 & 21.8 & 21.2 & 20.6 & 20.6 & 20 & 20 & 20 & 19.4 & 19.4 & 15 & 16 & 16 & 16 \\
\hline$S_{\min } 2008-2009$ & 23.7 & 23.7 & 23.2 & 22.7 & 22.2 & 21.7 & 21.2 & 20.8 & 20.8 & 18.9 & 18.9 & 18.9 & 16.9 & 16.9 & 19 & 20.2 & 20.2 & 20.2 \\
\hline$\Delta \mathrm{S}_{\min }$ & -0.5 & -0.5 & -0.4 & -0.3 & -0.2 & -0.1 & 0 & 0.2 & 0.2 & -1.1 & -1.1 & -1.1 & -2.5 & -2.5 & 4 & 4.2 & 4.2 & 4.2 \\
\hline
\end{tabular}
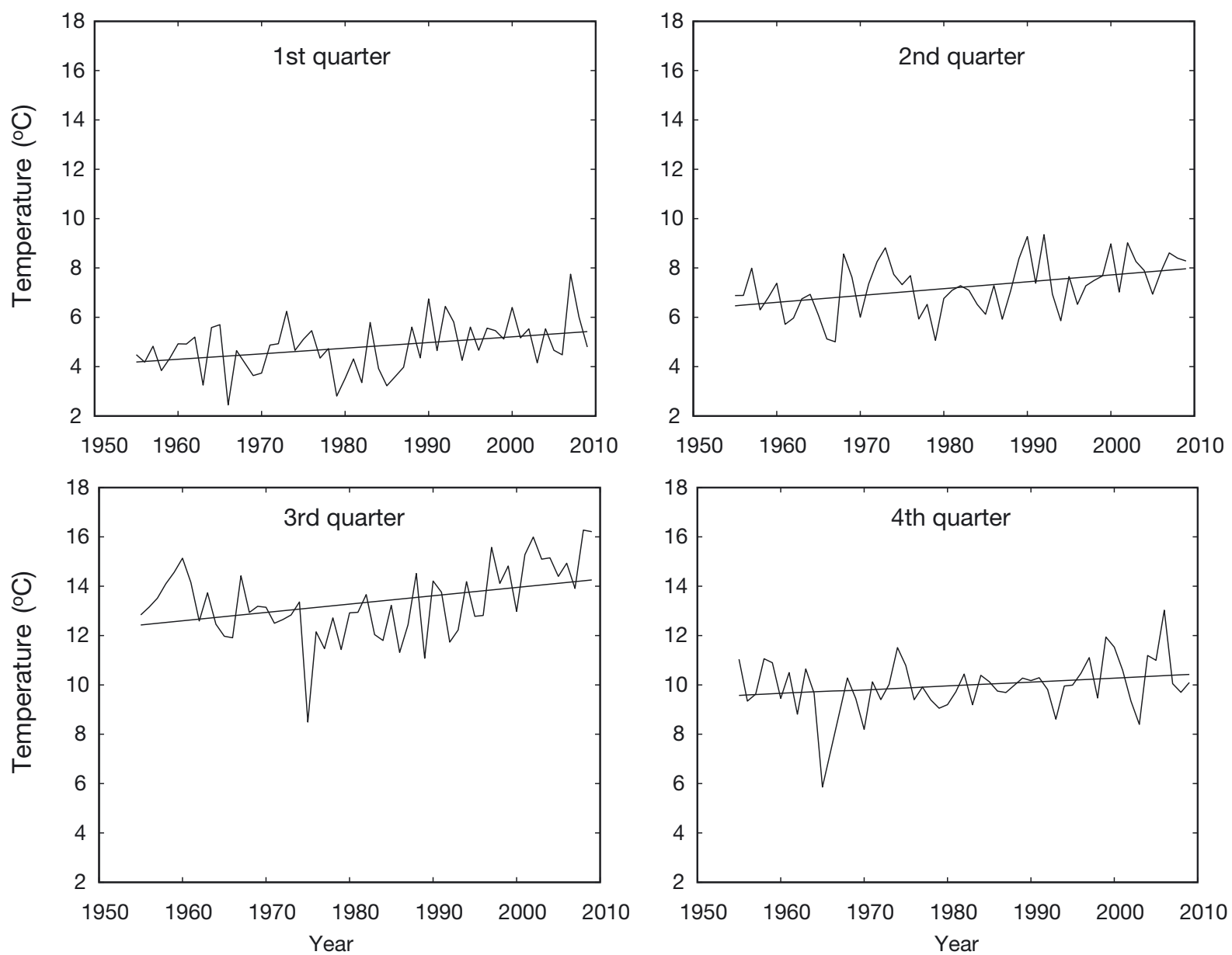

Fig. 3. Time series of temperature $\left({ }^{\circ} \mathrm{C}\right)$ at $10 \mathrm{~m}$ depth from the Utsira coastal monitoring station for annual quarters between 1955-2009: January-March (upper left), April-June (upper right), July-September (lower left) and October-December (lower right). Temperature exhibits a linear increase across all quarters 
mum temperatures during January-March did not differ strongly between 1955-1956 and 2008-2009, the temperatures during summer and early autumn were clearly higher throughout the fjord in 20082009 compared to the measurements in 1955-1956. This was most evident at 0 and $5 \mathrm{~m}$ depth, where the maximum temperature was $4.7^{\circ} \mathrm{C}$ and $4.5^{\circ} \mathrm{C}$ higher, respectively, in 2008-2009 compared to measurements from 1955-1956. The difference in maximum summer temperatures between 1955-1956 and 20082009 was highest in the inner part of the fjord proper (Stns 10-14) and lowest at the innermost stations (Stns 15-18) (Fig. 2, Table 1). Water temperatures observed at $10 \mathrm{~m}$ depth at Utsira coastal monitoring station (outside Hardangerfjord) revealed an upward trend from 1955 to 2009 for all quarters of the year, and the highest temperature increase was observed during summer to autumn (2nd and 3rd quarter of the year) (Fig. 3).

Salinity measured at Stns H3-H7 in the fjord varied between the 2 periods. During 1955-1956, the late autumn-to-winter maximum salinities at Stns H4-H7 were between 33 and 34 at 0 and $5 \mathrm{~m}$ depth, whilst ranging between 28 and 31 during 2008-2009 (Fig. 4). At the innermost hydrographical station (H3), the maximum salinity during 1955-1956 was 30.7 and 33.2 at 0 and $5 \mathrm{~m}$ depth, respectively, and $\sim 27$ (at both depths) during 2008-2009. At $10 \mathrm{~m}$ depth, the differences between the 2 periods were less pronounced.

Seasonal minimum salinity during summer to early autumn in the fjord was slightly lower at $0 \mathrm{~m}$ during 2008-2009 than during 1955-1956 (Fig. 4), and varied between 4.2 and 15.8 during 2008-2009, and 7.6 and 21.6 during 1955-1956, at the inner- and outermost hydrographical stations, respectively. The results also suggest more variability between monthly recordings of salinity at $0 \mathrm{~m}$ in 2008-2009 than in 1955-1956. At $5 \mathrm{~m}$ depth on the other hand, the minimum salinity recordings were much higher during 2008-2009 than during 1955-1956 in the innermost parts of the fjord (Fig. 4, Table 1). The minimum salinities were 16 and 14.2 in 1955-1956, and 20.2 and 19 in 2008-2009, at stations H3 and H4 respectively. Further out in the fjord there was a tendency towards slightly lower minimum salinity values at $5 \mathrm{~m}$ depth during 2008-2009 when compared with the results from 1955-1956. At $10 \mathrm{~m}$ depth only small differences in recordings of minimum salinity between 1955-1956 and 2008-2009 were found (Fig. 4).

Precipitation data from Eidfjord in the inner part of Hardangerfjord showed that there has been a more than $30 \%$ increase in the monthly mean values between 1955 and 2009 (Fig. 5). The shift in the seasonal cycle of freshwater run-off into Hardangerfjord following the large river regulations is illustrated by data from the regulated river at the hydroelectric plant Oksla in the inner part of Sørfjord and from the largest nearby unregulated river system. In the unregulated river the freshwater discharge displayed a typical pattern with low values during the winter, and a spring flood and an autumn flood with peak values of around $150 \mathrm{~m}^{3} \mathrm{~s}^{-1}$ (Fig. 6). The discharge from the regulated river at the Oksla hydroelectric power plant had a more steady discharge of fresh water on around $50 \mathrm{~m}^{3} \mathrm{~s}^{-1}$ (Fig. 6) with highest discharge in the cold season.

\section{Macroalgae communities}

Relatively few green macroalgae were included in the study; of these, Bryopsis hypnoides showed a clear increase in both distribution and abundance, while Codium fragile subsp. fragile showed a decrease (Fig. 7A). While many brown algae showed only minor changes in abundance and distribution between the 2 investigations, some displayed large changes; Acrothrix gracilis, Dictyota dichotoma, Stictyosiphon soriferus and Striaria attenuata showed a pronounced increase in both abundance and distribution range, while Dictyosiphon foeniculaceus and Protohalopteris radicans showed a clear decrease (Fig. 7A). There were also several species with a large negative shift in distribution ranges and little difference in abundance, e.g. Halosiphon tomentosus, Battersia racemosa and Battersia arctica. These occurred sparsely in the inner parts of the fjord in 1955-1956 but were not recorded in 2008-2009. Finally a few large and dominating species showed some increase in abundance without or with only a minor extension in distribution (Desmarestia aculeata, D. viridis, Saccharina latissima, and Laminaria hyperborea) (Fig. 7A). While L. hyperborea was not recorded in the fjord proper at all in 1955-1956 (Jorde \& Klavestad 1963), it was recorded at the 3 outer stations in 2008-2009. Most of the red algae showed an increase in both distribution range and abundance (Fig. 7B), while a few showed a decrease (Aglaothamnion tenuissimum, Dumontia contorta and Furcellaria lumbricalis). A few species also displayed a decrease in abundance without a concurrent shift in distribution range (Polyides rotunda, Corallina officinalis and Ceramium virgatum) (Fig. 7B).

Ordination analyses revealed strong correlations between species distributions and the environmental 
1955-1956
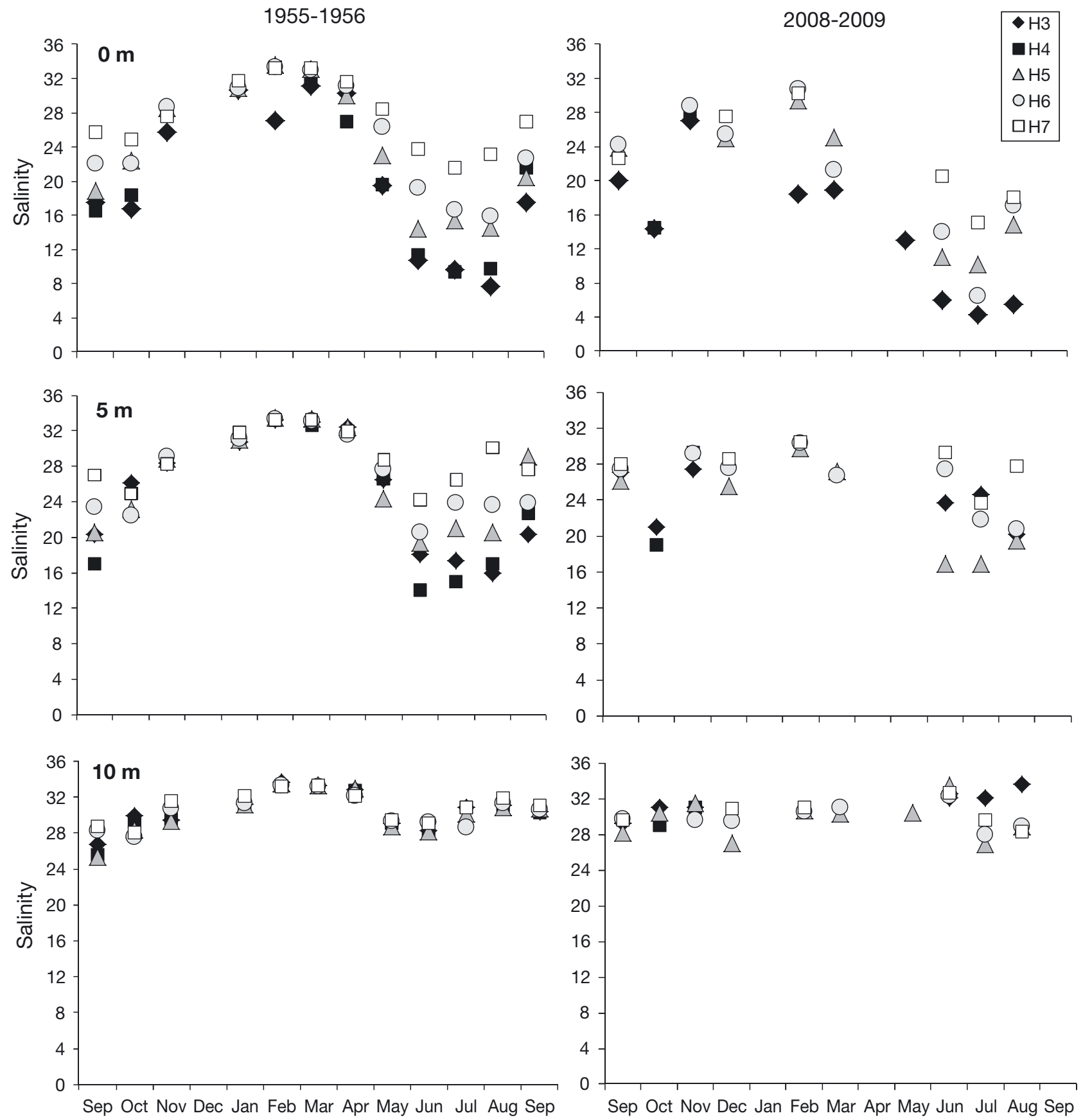

Fig. 4. Salinity recordings at 0, 5 and 10 m depth at Stns H3- H7 during earlier (1955-1956) and recent (2008-2009) investigation periods. The data plots for H6 in 2008-2009 consist of measurement averages from 2 new hydrographical stations, placed

$8 \mathrm{~km}$ further inside the fiord from Stn $\mathrm{H} 6$ and $10 \mathrm{~km}$ seaward of Stn H6

indexes, where gradients of maximum temperature and salinity stress (difference between maximum and minimum salinity during the year) were the strongest predictors. Significant correlations $(p=0.002)$ were identified between distributions of red, brown and green algae and the environmental indexes from both 5 and $10 \mathrm{~m}$ depths during the 2 investigation periods
(1955-1956 and 2008-2009). However, a lower percentage of the species' distributions were explained by environmental indexes at $10 \mathrm{~m}$ depth, and the $F$ values of the analyses were considerably higher when using the environmental indexes from $5 \mathrm{~m}$ depth. Therefore, the environmental indexes from $5 \mathrm{~m}$ depth were used in the subsequent analyses (Table 1). 


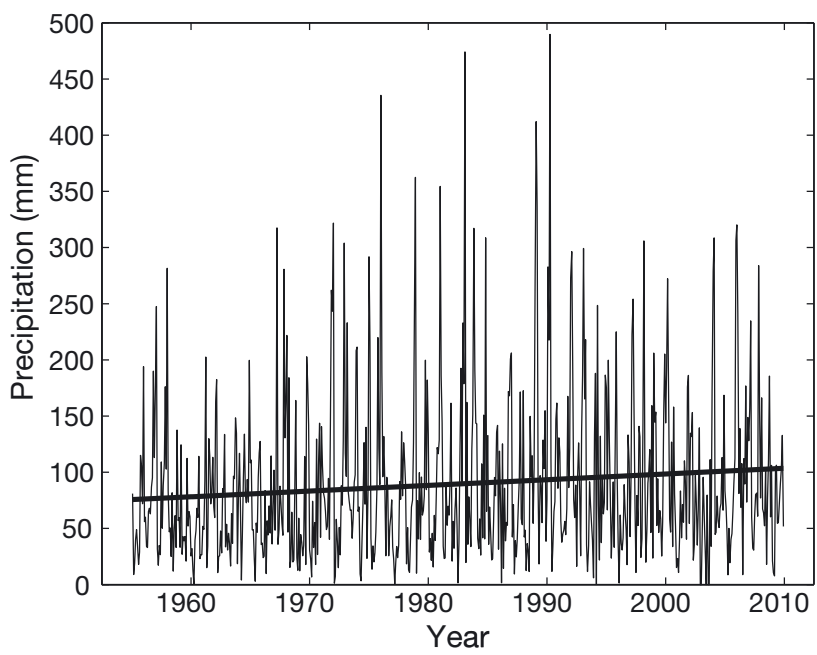

Fig. 5. Monthly precipitation ( $\mathrm{mm}$ ) and trend line from observations at the weather station in Eidfjord, in the inner part of the Hardangerfjord region

Distributions of the 5 species of green algae included in the analyses were most strongly correlated with the salinity gradients (Fig. 8). The results of the RDA analysis showed that $\sim 18 \%$ of the variation of the species distribution could be explained by the gradient of minimum salinity and $\sim 24 \%$ of all the canonical axes together $(F$-values $=7.1$ for first canonical axes, and 3.8 for all). The distribution of $C$. fragile subsp. fragile and Cladophora rupestris showed some degree of positive correlation with the gradient of minimum salinity (Fig. 8). However, the negative axis of salinity stress was not independent of the axis of minimum salinity for the green algae, which makes the interpretation of the analysis difficult. In addition, $C$. rupestris is an intertidal species, and environmental gradients at $5 \mathrm{~m}$ may not be representative for the salinity at $0 \mathrm{~m}$ depth. However, the decrease in the abundance and range shift of $C$. fragile subsp. fragile and range shift of C. rupestris in 2008-2009 compared to 1955-1956 (Fig. 7A) may be caused by greater fluctuations in salinity of the surface waters, and also an overall slight decrease in minimum salinity of the surface waters in the fjord proper during 2008-2009 (Fig. 4, Table 1). Bryopsis hypnoides showed a positive correlation with the gradient of maximum temperature (Fig. 8).

The brown algae distribution showed an overall strong negative correlation with an increasing salinity stress (Fig. 9). There was also strong positive correlations between the algal distribution pattern and both maximum temperature and minimum salinity, but the significance of the first canonical axis was much higher than for all the canonical axes ( $F$-value of the first canonical axis = 6.3 vs. 4.2 for all). The results of the RDA analysis showed that $\sim 16.4 \%$ of the variation of the species distribution could be explained by the gradient in salinity stress, and $\sim 28.2 \%$ by all 3 canonical axes together. The distribution of $B$. racemosa seemed to be positively correlated with increasing salinity stress, while the distributions of Cutleria multifida, $S$. latissima and Sphacelaria cirrosa were strongly negatively correlated (Fig. 9). Of these, B. racemosa showed a decrease in abundance and/or distribution in 2008-2009 when compared to the first study, while $S$. latissima and C. multifida showed an increase (Fig. 9). A high number of species showed a positive association with the gradient of minimum salinity (Fig. 9). These included large perennial algae such as Fucus serratus, F. spiralis, Halidrys siliquosa and Laminara digitata and L. hyperborea. However, except for the occurrence of $L$. hyperborea in the outer fjord in 2008-2009, none of these species showed large changes between the 2 surveys. In addition, the distributions of some species were associated with the gradient of maximum temperature (Fig. 9). H. tomentosus, B. arctica, P. radicans, D. foeniculaceus and Asperococcus fistulosus displayed a negative correlation with maximum temperature, while $S$. attenu-

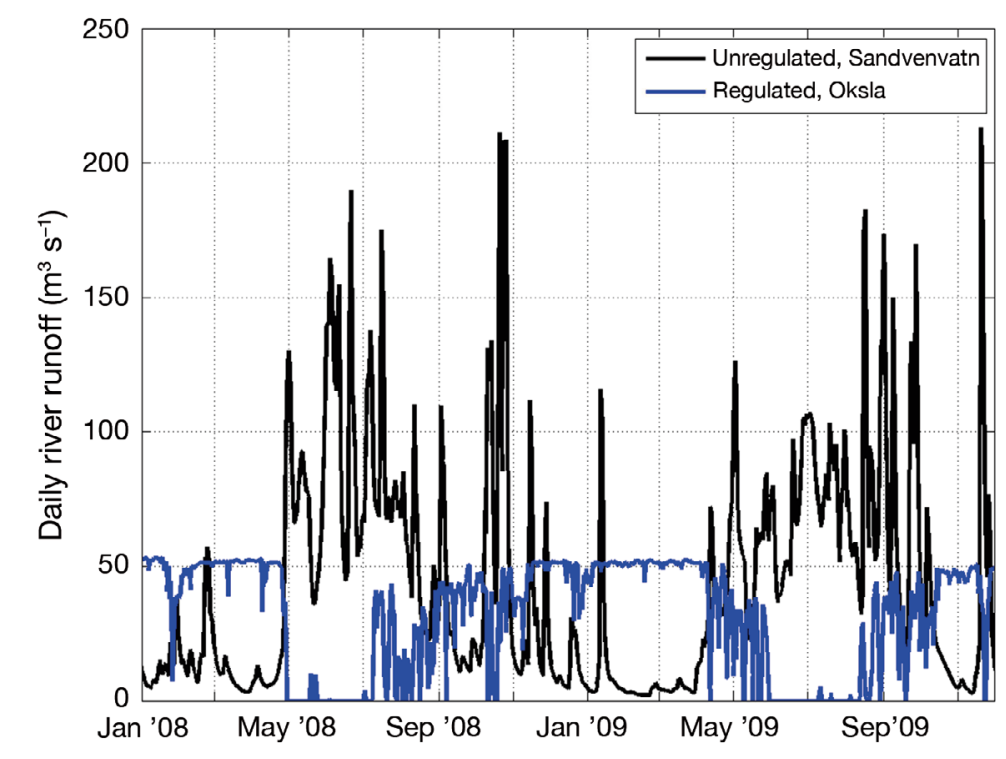

Fig. 6. Daily river runoff $\left(\mathrm{m}^{3} \mathrm{~s}^{-1}\right)$ during 2008 and 2009 from the unregulated river Sandvenvatn (black line) and from the hydroelectric power plant Oksla (blue line) in the inner part of Sørfjord 


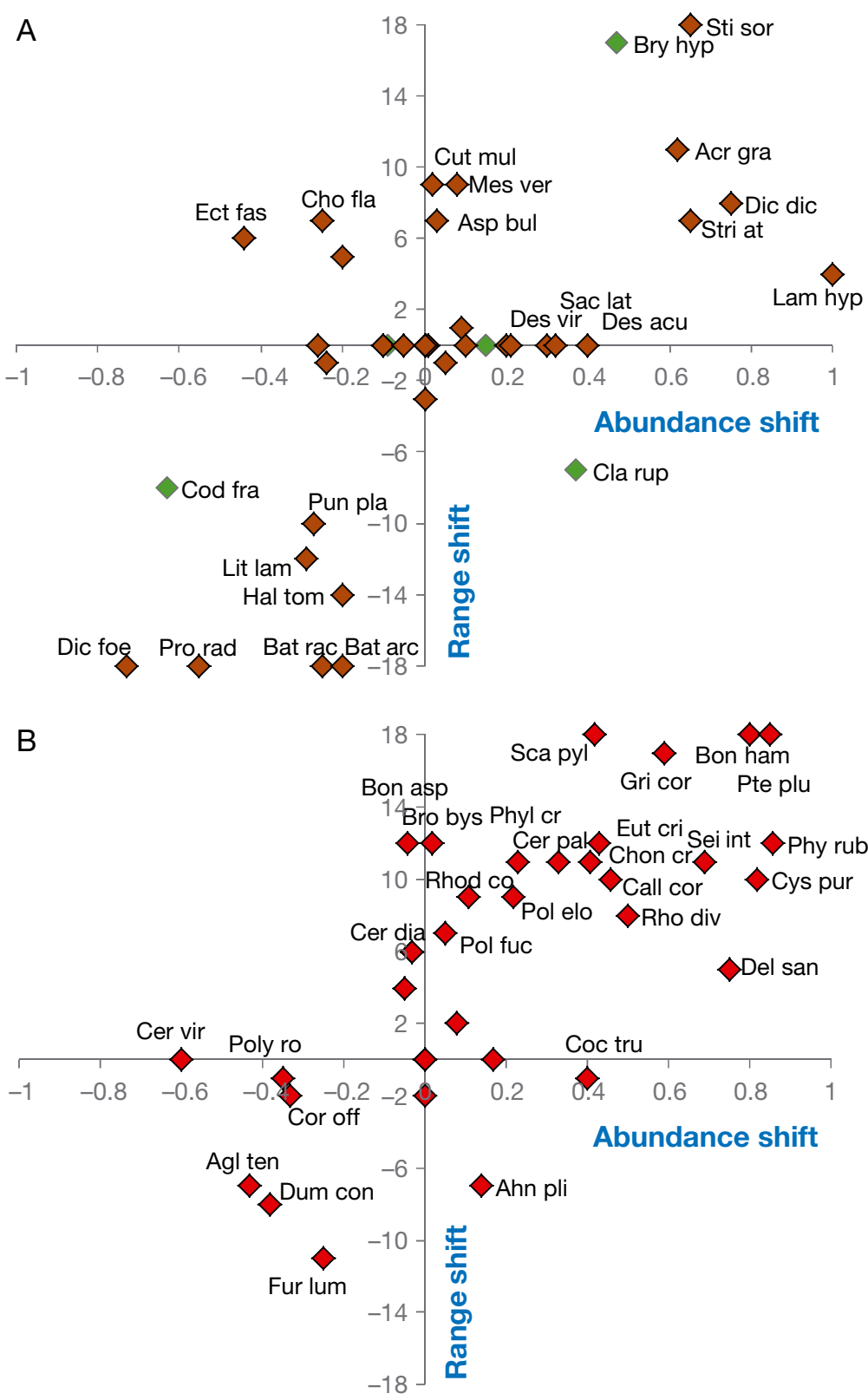

Fig. 7. Changes in range distribution and relative abundance of (A) brown and green algae and (B) red algae, between the early (1955-1956) and recent (2008-2009) investigation periods. Negative values represent range shifts towards the mouth of Hardangerfjord, or a decrease in abundance within the range of distribution compared to the first study. Species name definitions are given in Appendix 1, points not labelled are not referred to in the main text or the CANOCO analyses

ata showed a strong positive correlation. In addition, the distributions of $S$. soriferus, $D$. aculeata and $D$. viridis also showed some degree of positive correlation with the temperature maximum gradient. Most brown algae that displayed a negative correlation with maximum temperature also showed a decrease in abundance and/or distribution in 2008-2009 com- pared to 1955-1956, while those with a positive correlation showed an increase (Fig. 9).

The distribution of the red algae showed a strong positive correlation with the gradient of maximum temperature, and subsequently a significant negative correlation with increasing salinity stress. The $F$-value of the first canonical axis was substantially higher (13.1) than for all the canonical axes (6.8). Around $29 \%$ of the variation in the species distribution could be explained by the gradient in maximum temperature, while $\sim 36 \%$ was explained by all 3 canonical axes together. Among the red algae species, Pterothamnion plumula, Bonnemaisonia hamifera, Callithamnion corymbosun, Polysiphonia elongata and Scagelia pylaisaei displayed the strongest correlations with the maximum temperature gradient (Fig. 10). Another group (Cystoclonium purpureum, Lomentaria clavellosa, Polysiphonia fucoides, and Chylocladia verticillata) showed a strong negative correlation with increasing salinity stress. There was also a large group which appeared to have both a strong positive association with maximum temperature and a negative association with the salinity stress gradient, e.g. Phycodrys rubens, Brongniartella byssoides, Bonnemaisonia asparagoides, Chondrus crispus, Rhodomela confervoides, and Seirospora interrupta (Fig. 10). Most species with a clear positive association with maximum temperature or temperature in combination with a reduced salinity stress, showed a clear increase in abundance and/or range shift in the fjord in 2008-2009. Only a few of the red algae species that displayed a positive association with reduced salinity stress alone showed such an increase (Fig. 10). The distribution of Phyllophora pseudoceranoides showed some positive correlation with the gradient of minimum salinity, but did not differ in abundance or distribution in 2008-2009 compared to 1955-1956. Finally, a group of red algae (C. officinalis, $C$. virgatum and $P$. rotunda) were correlated with each other but were not well correlated with any of the environmental factors, except for a weak positive association with the gradient of minimum salinity (Fig. 10). These also showed a decrease in abundance in 2008-2009 when compared to 1955-1956, which may be associated with 


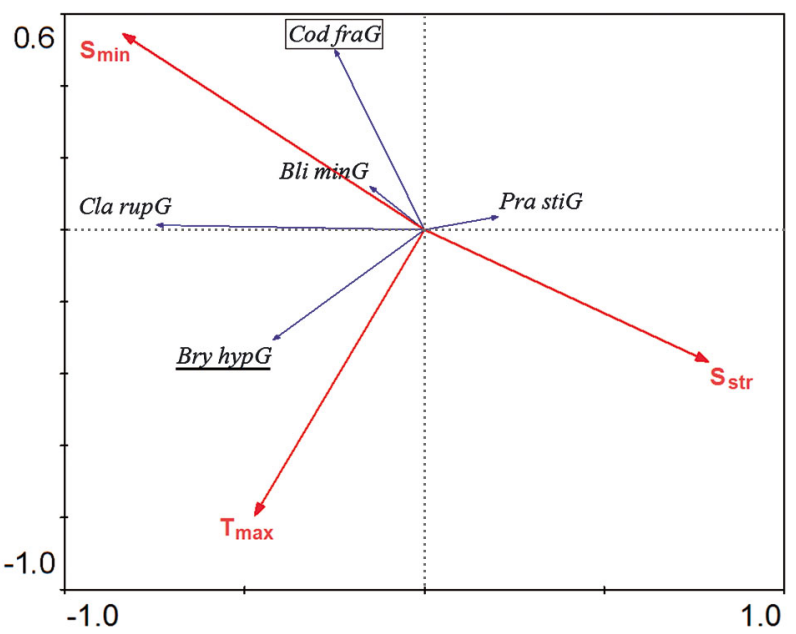

Fig. 8. Ordination of green algae distributions (G), and the environmental factors: $\mathrm{T}_{\max }=$ maximum summer temperature, $\mathrm{S}_{\min }=$ minimum salinity recordings, and $\mathrm{S}_{\mathrm{str}}=$ maximum variation in salinity, at the hydrographical Stns H3-H7 in Hardangerfjord during the 2 investigation periods. Species with increases in abundance $(\geq 30 \%)$ and/or distribution range ( $\geq 6$ sectors) between 1955-1956 and 2008-2009 are underlined; species with the same amounts of decrease in abundances and/or distribution ranges are framed. Species name definitions are given in Appendix 1

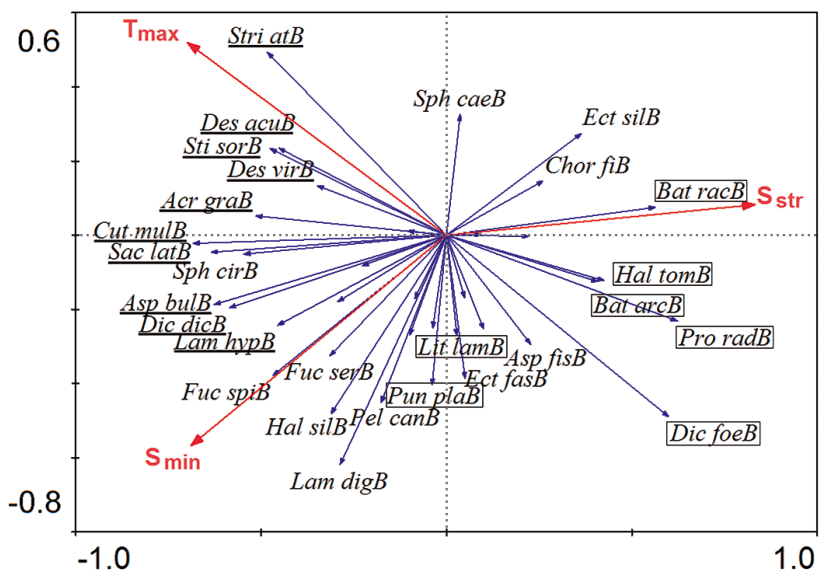

Fig. 9. Ordination of brown algae distributions (B), and the environmental factors: $\mathrm{T}_{\max }=$ maximum summer temperature, $\mathrm{S}_{\min }=$ minimum salinity recordings and $\mathrm{S}_{\mathrm{str}}=$ maximum variation in salinity, at the hydrographical Stns H3-H7 in Hardangerfjord during the 2 investigation periods. Species with increases in abundance $(\geq 30 \%)$ and/or distribution ranges ( $\geq 6$ sectors) between 1955-1956 and 2008-2009 are underlined, species with the same amounts of decrease in abundances and/or distribution ranges are framed. Species name definitions are given in Appendix 1

slightly lower values of minimum salinity at $5 \mathrm{~m}$ in the inner parts of the fjord proper in 2008-2009 compared to 1955-1956 (Table 1).

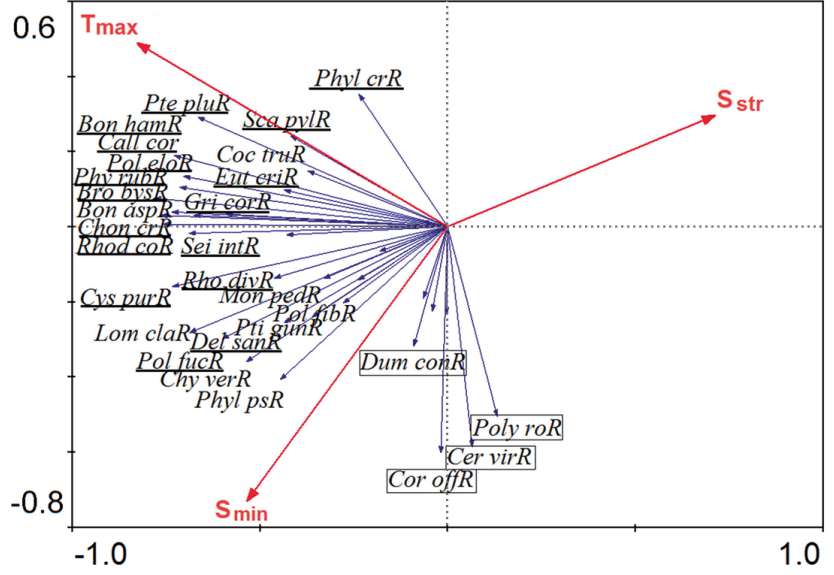

Fig. 10. Ordination of red algae distributions (R), and the environmental factors: $\mathrm{T}_{\max }=$ maximum summer temperature, $\mathrm{S}_{\min }=$ minimum salinity recordings, and $\mathrm{S}_{\mathrm{str}}=$ maximum variation in salinity, at the hydrographical Stns H3-H7 in Hardangerfjord during the 2 investigation periods. Species with increase in abundance $(\geq 30 \%)$ and/or distribution range ( $\geq 6$ sectors) between 1955-1956 and 2008-2009 are underlined; species with the same amounts of decrease in abundances and/or distribution ranges are framed. Species name definitions are given in Appendix 1

\section{DISCUSSION}

The strong correlations between the distributions of macroalgae and environmental indexes at $5 \mathrm{~m}$ depth indicate that temperature and salinity gradients in the shallow parts are most important in determining the horizontal macroalgal distribution in Hardangerfjord. High densities of sea urchins (Echinus acutus) and relatively little algal vegetation at many places below 2-8 $\mathrm{m}$ depth in Hardangerfjord has been documented in a recent (2009-2010; Husa et al. 2014) and earlier investigation (1955-1956; Jorde \& Klavestad 1963); thus this situation seems to have persisted over the last decades. However, during summer, when salinity is at its lowest in the surface layer, Husa et al. (2014) observed no sea urchins above $8 \mathrm{~m}$ in Hardangerfjord. This suggests that the brackish surface layer during summer keeps the sea urchin density low in the shallow subtidal, and that sea urchin grazing mainly takes place below $5 \mathrm{~m}$ depth. Consequently, the vegetation will be undisturbed in the upper depth range where it is most exposed to seasonal temperature and salinity variations.

One of the most conspicuous hydrographical changes in Hardangerfjord in 2008-2009 compared to 1955-1956 was the higher surface temperatures during summer. Temperatures at $10 \mathrm{~m}$ depth outside Hardangerfjord are representative of those in Hardangerfjord at this depth (Asplin et al. 2014). Conse- 
quently the long-term trend of increasing sea temperatures observed at the monitoring station outside Hardangerfjord, especially during summer, also applies to the fjord water. The temperature variations of the upper and most brackish layer are more variable and prone to year-to-year variation in surface fluxes. However, the higher summer temperature found at all examined depths in Hardangerfjord during 20082009 is in accordance with a relatively warm period (last 20 years) shown by meteorological observations (http://folk.uib.no/ngfhd/Climate/climate-t-utsira.html).

Differences in other environmental variables between 1955-1956 and 2008-2009 were also evident, such as lower winter salinity of the upper layers of the fjord waters and a less pronounced seasonal brackish layer in the fjord branch in 2008-2009. A long-term trend of decreasing salinity in the upper layers of Norwegian fjord water has also been reported by Aksnes et al. (2009). The salinity variations of the fjord water are due to both variations in freshwater run-off to the fjord and to variable salinity of the inflowing water from the coast. Furthermore, the changes in salinity are caused by both increased precipitation in coastal areas in south Norway, and by the fact that a large fraction of the spring and autumn flood has been redistributed mainly to the winter season due to hydroelectric power production. Around $93 \%$ of the hydroelectrical power production made from rivers to Hardangerfjord is due to river regulations made after 1955 , and $72 \%$ of this production has come from regulations of 2 large river systems ending in 2 inner fjord branches (Johnsen et al. 2007). The data of the present study show that the hydroelectrical power production has resulted in lower fresh water run-off to Hardangerfjord during spring and summer and higher run-off during winter, when compared to the natural hydrological pattern. The less pronounced seasonal brackish layer in the fjord branch, where salinity values at $5 \mathrm{~m}$ depth were higher in 2008-2009 compared to 1955-1956, is thus most likely due to the shift in freshwater run-off to the fjord. This, in combination with lower winter salinity, is the most likely cause for the reduced salinity stress (i.e. difference between maximum and minimum salinity during the year) in most parts of the fjord in 2008-2009, when compared to 1955-1956.

Clear differences in the responses of 3 macroalgal species groups to the environmental factors were observed in the present study. The red algal species showed a high degree of correlation with the maximum temperature gradient. Many species with higher abundances and increased range distributions in 2008-2009 compared to 1955-1956 showed a high degree of association with the maximum temperature gradient, demonstrating a positive effect of high 2008-2009 summer temperatures on many red algae. The study involved very few green algae, since only taxa identified to species were included in the analyses. With the exception of Bryopsis hypnoides, the distribution of the green algae was not affected by high summer temperatures in 2008-2009. The brown algae showed some positive response to the higher temperatures in the fjord during 20082009, but less than the red algae. This is in accordance with red algae generally having a higher affinity to warm water compared to brown algae (Price et al. 2006, Santelices et al. 2009). A likely consequence of higher sea temperatures in cold temperate zones is therefore that a number of red algal species may become more locally abundant. However, the results of the present study show that the reduced salinity stress during summer in 2008-2009 also had a strong positive effect on the occurrence of many red algae.

In estuaries such as Hardangerfjord, salinity may be more important than temperature in influencing the macroalgal composition, and salinity is known to influence the ratio between red and brown algae (Munda 1978, Middelboe et al. 1997, Schubert et al. 2011). Generally, red algae seem to be more sensitive to salinity than brown algae (Kain \& Norton 1990), and hypoosmotic treatment has, for example, been shown to more negatively affect photosynthesis in red algae than in brown algae (Kirst 1990). Based on compilations of field data collected along salinity gradients, Kain \& Norton (1990) suggested that a salinity around or slightly below 20 was a critically lower tolerance limit for many red algae. In the present study the salinity stress was the second most important environmental index explaining the distribution of red algae, but relatively few red algae showed a positive response to the reduced salinity stress alone. The combination of high summer temperature and reduced salinity stress seemed to have a more pronounced positive effect on red algae. The combined effects of salinities and temperatures on macroalgal growth have seldom been tested, however Hanisak (1979) found that the green alga Codium fragile subsp. fragile had a wider salinity tolerance when growing under optimum temperatures.

The brown algae showed less change in abundances and range shifts than the red algae, and were also less responsive to the increase in temperature from 1955-1956 to 2008-2009, even though some species showed a strong correlation with the maximum temperature gradient. The strong positive correlation between the temperature gradient and distri- 
bution of Striaria attenuata, and its increase in distribution range and abundance during 2008-2009, can be attributed to the relatively high summer temperatures since it has a high upper temperature limit of survival (Peters \& Breeman 1992). Some brown algae exhibited a clear decrease in occurrence in 2008-2009 compared to 1955-1956, and for some species, this decrease can be related to the higher temperature in 2008-2009. Battersia arctica has a clear northern distribution (Prud'homme van Reine 1982, Guiry \& Guiry 2014) and could be expected to decline with an increase in summer temperature, and the sporophytic stage of Halosiphon tomentosus has been shown not to grow at a temperature above $15^{\circ} \mathrm{C}$ (Sundene 1963). The apparent complete disappearance of the brown algae Dictyosiphon foeniculaceus and $P$. radicans from the area is on the other hand strange, since both species have been recorded much further south in Europe than the location of the present study area (Prud'homme van Reine 1982, Peters \& Breeman 1992) and they should thus be expected to tolerate summer temperatures above $15^{\circ} \mathrm{C}$. The abundance of Saccharina latissima was slightly higher in 2008-2009 compared to 1955-1956, and was associated with lower salinity stress. Consequently, the results of the present study suggest that summer temperatures up to $18-19^{\circ} \mathrm{C}$ do not seem to affect $S$. latissima negatively, while Sogn Andersen et al. (2013) showed that temperatures above $20^{\circ} \mathrm{C}$ are detrimental.

The members of the Order Fucales were more closely related to the salinity gradients than the temperature gradient, but their abundance and distribution range were relatively unaltered in 2008-2009 compared to 1955-1956. This can be attributed to the fact that species belonging to the Order Fucales are adapted to the littoral zone habitat which has extremely short time variations in salinity. The distributions of most brown algae with a pronounced increase in abundance or distribution range during 2008-2009 were associated with a decrease in salinity stress, either alone or in combination with increased summer temperature or an increase in the minimum salinity. However, we cannot rule out that other environmental factors, not included in the analyses here, can also be responsible for the observed changes in the vegetation. For example, Laminaria hyperborea occurred in the outer part of the fjord in 2008-2009, and its distribution showed some positive correlation with the gradient of minimum salinity in the study. However, the mini- mum salinity in the main fjord was slightly lower in 2008-2009 than in 1955-1956, and is, therefore, unlikely to be the underlying cause of the recent arrival of L. hyperborea in the fjord. The occurrence of L. hyperborea is on the other hand usually associated with high wave-exposure (Kain 1971), and the appearance of $L$. hyperborea in the outer part of the fjord in 2008-2009 may, therefore, be due to recent changes in wind patterns causing more waves in the outer area. Another example is Battersia racemosa, which appeared to have a clear positive association with increasing salinity stress and was not found in 2008-2009. This species normally occurs in sandy littoral pools (Prud'homme van Reine 1982) where salinity can vary much over short time spans. In the earlier study of the algal vegetation in Hardangerfjord, Battersia racemosa was found on a few localities in the infralittoral fringe of the innermost parts of the fjord proper and the fjord branches (Jorde \& Klavestad 1963). The decrease of this species in Hardangerfjord may be due to low competitive abilities in a presently less stressful habitat.

When comparing the results of the present study with those from the coastal area north of Hardangerfjord (Husa et al. 2008), some species appear to have recently increased in abundance according to both studies (Table 2). However, the increase in the abundances of species in Hardangerfjord is mostly associated with a reduction in salinity stress in 2008-2009 compared to 1955-1956, with the exception of 2 species (Phycodrys rubens and Pterothamnion plumula), whose increase can be fully or partly attributed to high summer temperatures. One of the reasons why the species related to decreased salinity stress have become more common in Hardangerfjord may be that there has been an increase in propagule pressure of these species, coming from the coastal area outside the fjord; for example, Dictyota dichotoma

Table 2. Macroalgae species that increased in abundance both in Hardangerfjord (this study) and the coastal area outside Hardangerfjord (Husa et al. 2008). The environmental index with the strongest association with each species distribution is given. $\mathrm{S}_{\mathrm{str}}=$ salinity stress, $\mathrm{T}_{\max }=$ maximum summer temperature, $\mathrm{R}=$ red algae, $\mathrm{B}=$ brown algae

\begin{tabular}{|ll|}
\hline Species & Environmental index \\
\hline Acrothrix gracilis (B) & $\mathrm{S}_{\text {str }}$ (negatively correlated) \\
Cystoclonium purpureum (R) & $\mathrm{S}_{\text {str }}$ (negatively correlated) \\
Delesseria sanguinea (R) & $\mathrm{S}_{\text {str }}$ (negatively correlated) \\
Dictyota dichotoma (B) & $\mathrm{S}_{\text {str }}$ (negatively correlated) \\
Phycodrys rubens (R) & $\mathrm{T}_{\text {max }}$ (positively)/ $\mathrm{S}_{\text {str }}$ (negatively) \\
Pterothamnion plumula (R) & $\mathrm{T}_{\text {max }}$ (positively correlated) \\
Rhodophyllis divaricata (R) & $\mathrm{S}_{\text {str }}$ (negatively correlated) \\
\hline
\end{tabular}


and Rhodophyllis divaricata have a northern limit of distribution in South Norway (Brattegard \& Holthe 1997) and are considered to have a warm-water affinity. While their increase in abundance on the coast of Norway can be due to higher sea water temperatures (Husa et al. 2008), their distribution within the fjord may still be limited by salinity stress.

Recently, there has been a large focus on the effects of increased sea temperatures and concurrent range shifts of seaweeds (e.g. Müller et al. 2009). Northwards migration of warm temperate macroalgae, or extinction of cold temperate and Arctic species in the southern part of their distribution ranges, will probably require increased sea water temperatures over a longer period of time. In Brittany, Gallon et al. (2014) observed a complex pattern of red algae responses to a warming over 2 decades, with declines in the occurrence rates of many warm-water red algae and increases in cold-water species. On the other hand, the results of the present study show that a local and episodic temperature increase of $3-5{ }^{\circ} \mathrm{C}$ will have a clear, positive effect especially on many red algal species present in the cold temperate Atlantic zone. Climate effects may, however, also involve community ecological shifts in competitive interactions and/or grazing intensity (Harley et al. 2012), which make predictions about changes in macroalgal distributions difficult. The results of the present study also show that a positive effect of higher summer temperatures on many red algae in estuaries could to some degree be associated with a mitigation of salinity stress. Since a pronounced climate change in the North Atlantic will most likely bring about a further increase in precipitation and sea temperatures, the combined effects of sea temperature and salinity changes on the macroalgae vegetation in estuaries could be more important than effects of temperature changes alone.

Acknowledgements. We are grateful to Hildur Pétursdóttir (Hafrannsoknanstofnunin, Iceland) for help with the CANOCO program and interpretation of the analyses; to Anders Ruus (NIVA, Norway) for information and permission to use hydrographical data; and to Vidar Wennevik (IMR, Norway) for producing the map in Fig. 1. We thank the referees for thorough reviews and good comments. The study was part of the EPIGRAPH project, supported by the Research Council of Norway.

\section{LITERATURE CITED}

Aksnes DL, Dupont N, Staby A, Fiksen Ø, Kaartvedt S, Aure J (2009) Coastal water darkening and implications for mesopelagic regime shifts in Norwegian fjords. Mar Ecol Prog Ser 387:39-49
Asplin L, Johnsen IA, Sandvik AD, Albretsen J, Sundfjord V, Aure J, Boxaspen KK (2014) Dispersion of salmon lice in the Hardangerfjord. Mar Biol Res 10:216-225

Benestad RE, Melsom A (2002) Is there a link between the unusually wet autumns in southeastern Norway and SST anomalies? Clim Res 23:67-79

Brattegard T, Holthe T (1997). Distribution of marine, benthic macro-organisms in Norway. A tabulated catalogue. Research Report No. 1997-1. Directorate for Nature Management, Trondheim

Breeman AM (1988) Relative importance of temperature and other factors in determining geographical boundaries of seaweeds - experimental and phenological evidence. Helgol Meersunters 42:199-241

> Dìez I, Muguerza N, Santolaria A, Ganzedo U, Gorostiaga JM (2012) Seaweed assemblage changes in the eastern Cantabrian Sea and their potential relationship to climate change. Estuar Coast Shelf Sci 99:108-120

Duarte L, Viejo RM, Martínez B, deCastro M, GómezGesteira M, Gallardo T (2013) Recent and historical range shifts of two canopy-forming seaweeds in North Spain and the link with trends in sea surface temperature. Acta Oecol 51:1-10

Eriksson BK, Johansson G (2005) Effects of sedimentation on macroalgae: species-specific responses are related to reproductive traits. Oecologia 143:438-448

Eriksson BK, Johansson G, Snoeijs P (2002) Long-term changes in the macroalgal vegetation of the inner Gullmar Fjord, Swedish Skagerrak coast. J Phycol 38: 284-296

Fortes MD, Lüning K (1980) Growth rates of North Sea macroalgae in relation to temperature, irradiance and photoperiod. Helgol Meersunters 34:15-29

Gallon RK, Robuchon M, Leroy B, Le Gall L, Valero M, Feunteun E (2014) Twenty years of observed and predicted changes in subtidal red seaweed assemblages along a biogeographical transition zone: inferring potential causes from environmental data. J Biogeogr 41: 2293-2306

Guiry MD, Guiry GM (2014) AlgaeBase. World-wide electronic publication, National University of Ireland, Galway. www.algaebase.org (accessed on: 24 March 2014)

Hanisak MD (1979) Growth patterns of Codium fragile ssp. tomentosoides in response to temperature. Mar Biol 50: 319-332

- Harley CDG, Hughes AR, Hultgren KM, Miner BG and others (2006) The impacts of climate change in coastal marine systems. Ecol Lett 9:228-241

Harley CDG, Anderson KM, Demes KW, Jorve JP, Kordas RL, Coyle TA, Graham MH (2012) Effects of climate change on global seaweed communities. J Phycol 48: 1064-1078

Hernández-Fariñas T, Soudant D, Barillé L, Belin C, Lefebvre A, Bacher C (2014) Temporal changes in the phytoplankton community along the French coast of the eastern English Channel and the southern Bight of the North Sea. ICES J Mar Sci 71:821-833

- Husa V, Sjøtun K, Brattenborg N, Lein TE (2008) Changes of macroalgal diversity in sublittoral sites in southwest Norway: impact of an introduced species or higher temperature? Mar Biol Res 4:414-428

> Husa V, Steen H, Sjøtun K (2014) Historical changes in macroalgal communities in Hardangerfjorden (Norway). Mar Biol Res 10:226-240 
Iles AC, Gouhier TC, Menge BA, Stewart JS, Haupt AJ, Lynch MC (2012) Climate-driven trends and ecological implications of event-scale upwelling in the California Current System. Glob Change Biol 18:783-796

Johnsen GH, Sægrov H, Urdal K, Kålås S (2007) Hardangerfjorden. Økologisk status 2007 og veien videre. Rådgivende Biologer AS rapport 1052 (in Norwegian)

Jorde I, Klavestad N (1963) The natural history of the Hardangerfjord. 4. The benthonic algal vegetation. Sarsia 9:1-99

Kaartvedt S (1984) Effects on fjords of modified freshwater discharge due to hydroelectric power production. Fisken Havet 3:1-104 (in Norwegian)

Kain JM (1971) Synopsis of biological data on Laminaria hyperborea. FAO Fish Synopses 87

Kain JM, Norton TA (1990) 15. Marine ecology. In: Cole KM, Sheath RG (eds) Biology of the red algae. Cambridge University Press, Cambridge, p 377-422

Kirst GO (1990) Salinity tolerance of eukaryotic marine algae. Annu Rev Plant Physiol 41:21-53

Krueger-Hadfield SA, Kuebler JE, Dudgeon SR (2013) Reproductive effort of Mastocarpus papillatus (Rhodophyta) along the California coast. J Phycol 49:271-281

Lenderink G, van Meijgaard E, Selten F (2009) Intense coastal rainfall in the Netherlands in response to high sea surface temperatures: analysis of the event of August 2006 from the perspective of a changing climate. Clim Dyn 32:19-33

Lepš J, Šmilauer P (2003) Multivariate analysis of ecological data using CANOCO. Cambridge University Press, Cambridge

Lifland J (2003) The North Atlantic Oscillation: climatic significance and environmental impact. EOS Trans Am Geophys Union 84: 73

Lima FP, Ribeiro PA, Queiroz N, Hawkins SJ, Santos AM (2007) Do distributional shifts of northern and southern species of algae match the warming pattern? Glob Change Biol 13:2592-2604

Liu D, Keesing JK, He P, Wang Z, Shi Y, Wang Y (2013) The world's largest macroalgal bloom in the Yellow Sea, China: formation and implications. Estuar Coast Shelf Sci 129:2-10

> Lotze HK, Worm B (2000) Variable and complementary effects of herbivores on different life stages of bloomforming macroalgae. Mar Ecol Prog Ser 200:167-175

Lüning K (1990) Seaweeds: their environment, biogeography and ecophysiology. John Wiley \& Sons, New York, NY

Middelboe AL, Sand-Jensen K (2000) Long-term changes in macroalgal communities in a Danish estuary. Phycologia 39:245-257

Middelboe AL, Sand-Jensen K, Brodersen K (1997) Patterns of macroalgal distribution in the Kattegat-Baltic region. Phycologia 36:208-219

Müller R, Laepple T, Bartsch I, Wiencke C (2009) Impact of oceanic warming on the distribution of seaweeds in polar and cold-temperate waters. Bot Mar 52:617-638

Munda IM (1978) Salinity dependent distribution of benthic algae in estuarine areas of Icelandic fjords. Bot Mar 21: 451-468

> Myksvoll MS, Sandvik AD, Asplin L, Sundby S (2014) Effects of river regulations on fjord dynamics and retention of coastal cod eggs. ICES J Mar Sci 71:943-956

> Parmesan C (2006) Ecological and evolutionary responses to recent climate change. Annu Rev Ecol Evol Syst 37: 637-669

Pedersen A, Kraemer G, Yarish C (2008) Seaweed of the littoral zone at Cove Island in Long Island Sound: annual variation and impact of environmental factors. J Appl Phycol 20:869-882

Peters AF, Breeman AM (1992) Temperature responses of disjunct temperate brown algae indicate long-distance dispersal of microthalli across the tropics. J Phycol 28:428-438

Petterson LE (2008) Beregning av totalavløp til Hardangerfjorden. Norges Vassdrags- og Energidirektorat. Oppdragsrapport A nr 92008 (in Norwegian)

> Price ARG, Vincent LPA, Venkatachalam AJ, Bolton JJ, Basson PW (2006) Concordance between different measures of biodiversity in Indian Ocean macroalgae. Mar Ecol Prog Ser 319:85-91

Prud'homme van Reine WF (1982) A taxonomic revision of the European Sphacelariaceae (Sphacelariales, Phaeophyceae). Leiden Bot Ser 6:1-293

Sælen OH (1962) The natural history of the Hardangerfjord 3. The hydrographical observations 1955-1956: tables of observations and longitudinal sections. Sarsia 6:1-25

Sætre R, Aure J, Danielssen DS (2003) Long-term hydrographic variability patterns off the Norwegian coast and in the Skagerrak. ICES Mar Sci Symp 219:150-159

Sangil C, Sansón M, Afonso-Carillo J, Herrera R, Rodríguez A, Martín-García L, Díaz-Villa T (2012) Changes in subtidal assemblages in a scenario of warming: proliferations of ephemeral benthic algae in the Canary Islands (eastern Atlantic Ocean). Mar Environ Res 77:120-128

Santelices B, Bolton JJ, Meneses I (2009) Marine algal communities. In: Whitman JD, Roy K (eds) Marine macroecology. Chicago University Press, Chicago, p 153-192

Scavia D, Field JC, Boesch DF, Buddemeier RW and others (2002) Climate change impacts on U.S. coastal and marine ecosystems. Estuaries 25:149-164

Schubert H, Feuerpfeil P, Marquardt R, Tlesh I, Skarlato S (2011) Macroalgal diversity along the Baltic Sea salinity gradient challenges Remane's species-minimum concept. Mar Pollut Bull 62:1948-1956

Sogn Andersen G, Pedersen MF, Nielsen SL (2013) Temperature acclimation and heat tolerance of photosynthesis in Norwegian Saccharina latissima (Laminariales, Phaeophyceae). J Phycol 49:689-700

Sundby S, Nakken O (2008) Spatial shifts in spawning habitats of Arcto-Norwegian cod related to multidecadal climate oscillations and climate change. ICES J Mar Sci 65: 953-962

Sundene O (1963) Reproduction and ecology of Chorda tomentosa. Nytt Magasin for Botanikk 10:159-167

Tanaka K, Taino S, Hiroko H, Prendergast G, Hiraoka M (2012) Warming off southwestern Japan linked to distributional shifts of subtidal canopy-forming seaweeds. Ecol Evol 2:2854-2865

Valiela I, McClelland J, Hauxwell J, Behr PJ, Hersh D, Foreman K (1997) Macroalgal blooms in shallow estuaries: controls and ecophysiological and ecosystem consequences. Limnol Oceanogr 42:1105-1118

van den Hoek C (1982a) The distribution of benthic marine algae in relation to the temperature regulation of their life histories. Biol J Linn Soc 18:81-144

- van den Hoek C (1982b) Phytogeographic distribution groups of benthic marine algae in the North Atlantic Ocean. A review of experimental evidence from life history studies. Helgol Meersunters 35:153-214

- Walker DI, Kendrick GA (1998) Threats to macroalgal diversity: marine habitat destruction and fragmentation, pollution and introduced species. Bot Mar 41:105-112

> Worm B, Lotze HK (2006) Effects of eutrophication, grazing, and algal blooms on rocky shores. Limnol Oceanogr 51: 569-579 
Appendix 1. Species from 20 stations in Hardangerfjord, with name abbreviations. Nomenclature follows Guiry \& Guiry (2014). * Species not included in CANOCO analyses

\begin{tabular}{|c|c|c|c|}
\hline Taxon & Abbrev. & Taxon & Abbrev. \\
\hline CHLOROPHYTA & & RHODOPHYTA & \\
\hline Blidingia minima (Nägeli ex Kützing) Kylin & Bli min & Aglaothamnion tenuissimum (Bonnemaison) & Agl ten \\
\hline Bryopsis hypnoides J.V. Lamouroux & Bry hyp & Feldmann-Mazoyer & \\
\hline Bryopsis plumosa (Hudson) C. Agardh & Bry plu* & Ahnfeltia plicata (Hudson) Fries & Ahn pli \\
\hline Cladophora rupestris (Linnaeus) Kützing & Cla rup & Bonnemaisonia asparagoides (Woodward) & Bon asp \\
\hline Codium fragile subsp. fragile (Suringar) Hariot & Cod fra & C. Agardh & \\
\hline Prasiola stipitata Suhr ex Jessen & Pra sti & Bonnemaisonia hamifera Hariot & Bon ham \\
\hline Ulva lactuca Linnaeus & Ulv lac $^{*}$ & Brong & Bro bys \\
\hline PHAEOPHYCEAE & & $\mathrm{Sc}$ & \\
\hline Acrothrix gracilis Kylin & Acr gra & Callithamnion corymbosum (Smith) Lyngbye & Call cor \\
\hline Ascophyllum nodosum (L.) Le Jolis & Asc nod ${ }^{*}$ & Ceramium diaphanum (Lightfoot) Roth & Cer dia \\
\hline Asperococcus bullosus J.V. Lamouroux & Asp bul & Ceramium virgatum Roth & Cer vir \\
\hline Asperococcus fistulosus (Hudson) Hooker & Asp fis & Ceramium tenuicorne (Kützing) Wærn & Cer ten \\
\hline Battersia arctica (Harvey) Draisma, & Bat arc & $\begin{array}{l}\text { Ceramium pallidum (Nägeli ex Kützing) } \\
\text { Maggs \& Hommersand }\end{array}$ & Cer pal \\
\hline Prud & & Chondrus crispus Stackhouse & Chon $\mathrm{cr}$ \\
\hline $\begin{array}{l}\text { Battersia racemosa (Greville) Draisma, } \\
\text { Prud'homme \& H.Kawai }\end{array}$ & Bat rac & Chylocladia verticillata (Lightfoot) Bliding & Chy ver \\
\hline Chaetopteris plumosa (Lyngbye) Kützing & Cha plu & Coccotylus truncatus (Pallas) Wynne \& Heine & Coc tru \\
\hline Chorda filum (L.) Stackhouse & Chor fi & Compsothamnion thuyoides (J.E.Smith) Nägeli & Com thy* ${ }^{*}$ \\
\hline Chordaria flagelliformis (Müller) C.Agardh & Cho fla & orallina officinalis Linnaeus & Cor off \\
\hline Cladostephus spongiosus (Hudson) C.Agardh & Cla spo* & Cystoclonium purpureum (Hudson) Batters & Cys pur \\
\hline Cutleria multifida (J.E. Smith) Greville, & Cut mul & $\begin{array}{l}\text { Delesseria sanguinea (Hudson) Lan } \\
\text { Dilsea carnosa (Schmidel) Kuntze }\end{array}$ & $\begin{array}{l}\text { Del san } \\
\text { Dil car* }\end{array}$ \\
\hline & & Dumontia contorta (Gmelin) Ruprecht & Dum con \\
\hline Desmarestia aculeata (L.) Lamouroux & Des acu & Euthora cristata (C. Agardh) Kützing & Eut cri \\
\hline Desmarestia viridis (Müller) Lamouroux & Des vir & Furcellaria lumbricalis (Hudson) Lamouroux & Fur lum \\
\hline Dictyosiphon foeniculaceus (Hudson) Greville & Dic foe & Gelidium spinosum (Gmelin) Silva & Gel spi* \\
\hline $\begin{array}{l}\text { Dictyo } \\
\text { Ectoca }\end{array}$ & IC & Griffithsia corallinoides (L.) Trevisan & Gri cor \\
\hline n) Lyngbye & 1 & Hildenbrandia rubra (Sommerfelt) Meneghini & Hil rub* \\
\hline Y schoug & is & Lomentaria clavellosa (Turner) Gaillon & Lom cla \\
\hline schoug & fuc & Lomentaria orcadensis (Harvey) & Lom orc ${ }^{*}$ \\
\hline $\begin{array}{l}\text { Fucus serrati } \\
\text { Fucus spirali }\end{array}$ & Fuc ser & Collins ex Taylor & \\
\hline $\begin{array}{l}\text { Fucus spirali } \\
\text { Fucus vesicu }\end{array}$ & Fuc $s$ & Mastocarpus stellatus (Stackhouse) Guiry & Mas ste* \\
\hline $\begin{array}{l}\text { Fucus vesiculc } \\
\text { Halidrys siliqu }\end{array}$ & jes & pedicellatus (Smith) Solier & Mon ped \\
\hline $\begin{array}{l}\text { Hallarys sillque } \\
\text { Halosiphon ton }\end{array}$ & Hal sil & Palm & Pal pal* \\
\hline Haplospora globosa & ${ }^{*}$ & Phycodrys & Phy rub \\
\hline Hinkcsia sandrina ( & Hin $\operatorname{san}^{*}$ & Phyllophora pseudoceranoides (Gmelin) & Phyl ps \\
\hline Laminaria digitata (Hudson) Lamouroux & Lam dig & th \& Taylor & \\
\hline Laminaria hyperbor & Lam hyp & phora crispa $(\mathrm{Hu}$ & Phyl cr \\
\hline Litosiphon laminariae (Lyngbye) Harvey & Lit lam & ) Kuntze & Plu plu* \\
\hline Mesogloia vermiculata (Smith) Gray & Mes ver & n) Gaillon & Poly ro \\
\hline Pelvetia canaliculata (L.) Decaisne \& Thuret & Pel can* & Hudson) Spre & Pol elo \\
\hline Protohalopteris radicans (Dillwyn) Draisma, & Pro rad & Polysiphonia fibrillo & Pol fib \\
\hline Prud'homme \& H.Kawai & & Polysiphonia fucoides (Hudson) Greville & Pol fuc \\
\hline Punctaria plantaginea (Roth) Greville & Pun pla & cta (Dillwyn) Greville & Pol str \\
\hline Pylaiella littoralis (L.) Kjellman & Pyl lit* & exJE Ar & Por co \\
\hline $\begin{array}{l}\text { Saccharina latissima (L.) C.E. Lane, C. Mayes, } \\
\text { Druehl \& G.W. Saunders }\end{array}$ & Sac lat & Ptilota gunneri Silva, Maggs \& Irvine & Pti gun \\
\hline Scytosiphon lomentaria (Lyngbye) Link & & Pter & Pte pl \\
\hline Spermatochnus paradoxus (Roth) Kützing & Spe par & Pterosiphonia parasitica (Hudson) Falkenberg & Pte par* \\
\hline Sphacelaria cirrosa (Roth) C.Agardh & Sph cir & Rhodomela confervoides (Hudson) Silva & Rhod co \\
\hline Sphacelaria nana Nägeli ex Kützing & Sph nan* & Rhodomela lycopodioides (L.) C. Agardh & Rhod ly* \\
\hline Sphacelaria plumula Zanardini & Sph plu* & Rhodophyllis divaricata (Stackhouse) Papenfuss & Rho div \\
\hline caespitulum (Lyngbye) & Sph cae & ia pylaisaei (Montagne) M.J. Wynne & Sca pyl \\
\hline Draisma, Prud'homme \& H.Kawai & & Sei & Sei int \\
\hline Spongonema tomentosum (Hudson) Kützing & Spo tom & Schm & Sch hi \\
\hline Stictyosiphon soriferus (Reinke) Rosenvinge & Sti sor & (Dillwwyn) Rosen & Sne $r e$ \\
\hline Stictyosiphon tortilis (Ruprecht) Reinke & Sti tor & $V$ & $\mathrm{Y}$ \\
\hline $\begin{array}{l}\text { Striaria attenuata (C. Agardh) Greville, } \\
\text { (Greville) Greville }\end{array}$ & Stri at & & \\
\hline Tilopteris mertensii (Turner) Kützing & IIIIer & & \\
\hline
\end{tabular}

